\title{
Biomedical Instrument Application: Medical Waste Treatment Technologies
}

\author{
Muhammed Gulyurt \\ Fatih University \\ Turkey
}

\section{Introduction}

According to the Ministry of Environment of Turkish Republic (CYGM),(2005) medical waste comes out of the premises whose activities result in waste production, such as university hospitals and clinics, general purpose hospitals and clinics, maternity hospitals and clinics, military hospitals and clinics, health centers, medical centers, dispensaries, ambulatory medical centers, morgues and postmortem examination centers, vivisectionist entities, nursing homes and old-age asylums, medical and biomedical laboratories, veterinary hospitals, blood banks and transfusion centers, emergency and first aid centers, dialysis centers, rehabilitation centers, biotechnological laboratories and institutes, medical research centers, other units of health service (doctor offices, mouth and dental health surgeries and so on), veterinary clinics, acupuncture centers, physiotherapy centers, domiciliary treatment and nursing services, centers of beauty, ear-piercing and tattoo, pharmacies, ambulance services and zoological gardens. [1]

In addition, WHO emphasizes that at the domestic level, municipalities, some entities, private companies or organized non-governmental organizations carry out the collection and processing of medical waste through some necessary measures taken by healthcare organizations. Unless the microorganisms contained by the medical waste are collected and made ineffective in a controlled manner, firstly, the medical, then it becomes a threat against public health. ${ }^{[2]}$ Through countries which can not dispose of the hospital waste satisfactorily, some certain diseases are frequently observed in society. Open wound infections, typhoid, gastric, diarrhea, cholera, Hepatitis B and Hepatitis C and HIV threatens mainly doctors' health, nurses and patient careers.[3] It is largely estimated that 21 million people are exposed to HBV, 2 million people to $\mathrm{HCV}$, and 260,000 people to HIV viruses due to the repeated use of unsterilized injections. According to the WHO report, some of the re-use disposable syringes countries are African, Asian, and Central and Eastern European countries. [2]

However, considering the risks of contamination of extremely dangerous communicable viruses, such as Hepatitis B and HIV, through humans, some regulations and laws are put into effect in order to take some precautions necessary for the control and disposal in the premises which produce waste, to process the medical waste separate from others by 
preventing any harm against public health and environment. Those regulations describe the overall procedure in a detailed way, from the identification of medical waste to its collection and disposal.

Moreover, European Union waste management strategy Council Directive 75/442/EEC, [4] dated 15 July 1975 was repealed on 5 April 2006; and it has been determined to the European Parliament and Council Directive 2006/12/EEC, [5]. In the abovementioned directive, there are some definitions of waste, and classifications of the waste categories included in the directive, and outlines of disposal and recycling activities. The appendix of the directive comprises some provisions which constitute the foundations and main principles of the waste management regarding the waste types outside the coverage, general principles with respect to the waste management, formation of the authorities, the waste management plans, the liabilities of the enterprises which are involved in the recycling and disposal activities, their obligation to hold records and their periodical auditing, the waste disposal expenses covered within the scope of the polluter pays principle and producer responsibilities.

Furthermore, the Commission Resolution 2000/532/EC (2000)[6] underlined that the principles of compiling a common list for waste and hazardous waste to be used in community, in compliance both with Waste Framework Directive and the Council Directive 91/689/EEC, [7] on the hazardous waste. The Waste Framework Directive and the directive of waste list are both adopted by the member countries of European Union, and incorporated into "the directives to be primarily adjusted" ${ }^{[7]}$ sections in the countries in the European Union accession process, such as Turkey. While the regulations and laws vary at the level of states in the USA, it is determined in some international congresses and seminars that they are one step ahead of the European countries.

\section{The historical background in the USA}

The classification of medical waste was one of the most important questions in terms of the U.S. regulations during 1970s. Its officially first recognition as a distinct waste type was provided by a federal agency in 1978. EPA's approach to the question was one step further in the sense that it principally described infectious waste, i.e. medical waste, under the category of hazardous waste in compliance with the Resource Conservation Recovery Act (RCRA). Thus, although the EPA's proposition for hazardous waste regulations includes infectious wastes as proclaimed in RCRA in 1980, the agency refused that medical wastes did not constitute any serious threat to public health and environment.

Looking at the implementations in European countries and the USA, it can be observed that there are numbers of systems of the medical waste disposal. Besides within the scope of the sterilization methods as the primary Medical Waste Treatment Technologies, there are oxygenic, ozonic and oxygen-free methods of disposing which are preferred in large integrated plants. Although burning is exactly a disposal method, it is not preferred by some countries since a considerable amount of hazardous soot and ash comes out of the burning operation. Expenditures seem to be important in the choice of Medical Waste Treatment Technology methods. Yet, the resolutions taken by the governments and the laws to which they are subjected are directing factors in their choices. The purpose of this chapter is to analyse the analyze the Medical Waste Treatment Technologies. 


\section{What are the hazardous medical wastes}

Medical waste is defined by the World Health Organization as "a broad range of materials such as used needles and syringes to soiled dressings, body parts, diagnostic samples, blood, chemicals, pharmaceuticals, medical devices and radioactive materials which are produced health care clinics, centers, hospitals and laboratories." $[8]$

Through European Union Legislation 75/442/EEC [4] dated 15 July 1975 defines the meaning of "waste", while the Council Directive describes "hazardous waste" in the European Union Legislation 91/689/EEC [7] on 12 December 1991. Within the European Union Legislations, the descriptions of the types of hazardous wastes, the precautions to be made, the waste management, the transmission and disposal of hazardous wastes are available. The countries in the European Union accession process, on the other hand, exercise those regulations in the period grated in accordance with the course of the process.

\subsection{International biotechnology logo}

The biohazard symbol which is associated with the term "biological hazards" simply means that it is extremely important to take precautions due to a potential exposition of the materials threatening public heath. The Dow Chemical Company first designed the symbol for their waste storages in 1966. [9]

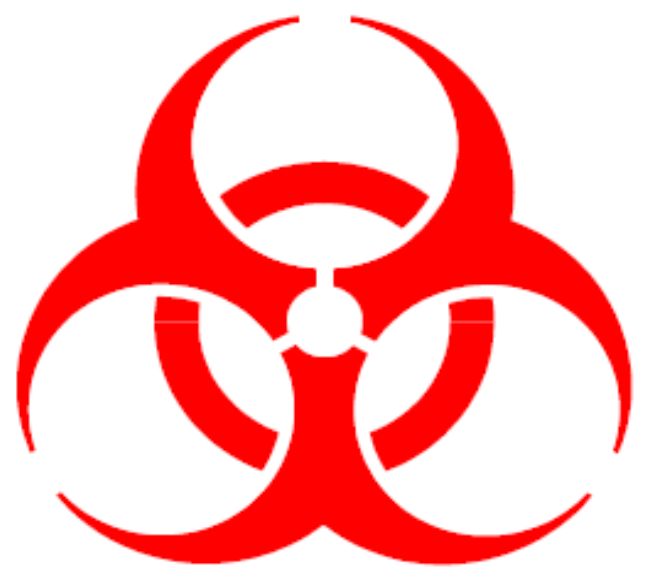

Fig. 1. Biohazard warning symbol. The sign color stipulated in the standard form is fluorescent orange-red. [9]

\subsection{What is the medical waste categories?}

The European Union Council Directive 67/548/EEC [10] was promulgated on 27 June 1967, with respect to the adjustment of laws, regulations and administrative provisions regarding the classification, packaging and labeling of hazardous waste. Based on this directive, the Ministry of Environment and Forestry of Turkish Republic published "the Regulations for the Medical Waste Control 25883" on July 22, 2005, [1] and classified the wastes collected from hospitals and health care organizations as follows. 


\begin{tabular}{|c|c|c|c|c|}
\hline \multicolumn{5}{|c|}{ Classification of the wastes stemming from health care organizations } \\
\hline \multicolumn{2}{|c|}{$\begin{array}{l}\text { Household wastes } \\
\left(2003^{*} \text { and } 1501^{*}\right)\end{array}$} & \multicolumn{3}{|c|}{\begin{tabular}{|c|} 
Medical wastes \\
$\left(1801^{*}\right.$ and $\left.1802^{*}\right)$
\end{tabular}} \\
\hline $\begin{array}{l}\text { A: General Wastes } \\
200301^{*}\end{array}$ & $\begin{array}{l}\text { B: Packing Wastes } \\
150101^{*}, 150102^{*}, 1501 \\
04^{*}, 150105^{*}, 150106^{*}, 15 \\
01 \quad 07^{*}\end{array}$ & $\begin{array}{l}\text { C: Infectious Wastes } \\
180103^{*} \text { and } \\
180202^{*}\end{array}$ & \begin{tabular}{|l|} 
D: Pathological Wastes \\
$180102^{*}$
\end{tabular} & $\begin{array}{l}\text { E:Sharp Wastes } \\
180101^{*} \text { and } \\
180201^{*}\end{array}$ \\
\hline $\begin{array}{l}\text { Parts with the presence of } \\
\text { healthy people, sections in } \\
\text { which those who are not } \\
\text { patient are treated, first aid } \\
\text { areas, administrative units, } \\
\text { cleaning services, kitchens, } \\
\text { wastes coming from } \\
\text { storehouses and workshops: } \\
\text { any wastes arising from } \\
\text { medical centers excluding } \\
\text { those mentioned in the } \\
\text { groups B, C,D,E, F and G, }\end{array}$ & $\begin{array}{l}\text { Reusable and recyclable } \\
\text { wastes coming from all } \\
\text { administrative units, } \\
\text { kitchens, storehouses, } \\
\text { workshops, etc. : } \\
\text {-paper } \\
\text {-cardboard } \\
\text {-paperboard } \\
\text {-plastic } \\
\text {-glass } \\
\text {-metal, etc. }\end{array}$ & $\begin{array}{l}\text { Wastes which requires special } \\
\text { treatment for their transmission } \\
\text { and disposal in order to prevent } \\
\text { the expanding of infectious } \\
\text { agents: } \\
\text { Microbiological laboratory } \\
\text { wastes } \\
\text { Cultures and stocks } \\
\text { Infectious body liquids } \\
\text { Serologic wastes } \\
\text { Other contaminated laboratory } \\
\text { wastes (lamina, lamella, pipette, } \\
\text { petri, etc.) } \\
\text { Blood, blood products and any } \\
\text { materials contaminated with } \\
\text { those } \\
\text { Used surgical clothes (fabric, } \\
\text { gowns, gloves, etc. ) } \\
\text { Dialysis wastes (sewage and } \\
\text { equipments) } \\
\text { Quarantine wastes } \\
\text { Air filters contaminated with } \\
\text { bacteria and viruses } \\
\text { Experimental animal carcasses, } \\
\text { organ parts, their blood, and any } \\
\text { materials touched by those }\end{array}$ & \begin{tabular}{|l|} 
Anatomical tissue \\
wastes, parts of organs \\
and bodies along with \\
body liquids coming \\
out during a medical \\
treatment such as \\
surgery, autopsy, etc.: \\
body parts, organic \\
parts, placenta, and \\
separated organs, etc. \\
stemming from \\
surgery rooms, \\
morgues, autopsies, \\
forensic medicine \\
(humane pathological \\
wastes) \\
Guinae pig carcasses \\
used in biological \\
experiments
\end{tabular} & $\begin{array}{l}\text { Wastes which may } \\
\text { cause pinprick, sharp, } \\
\text { scar and any injuries: } \\
\text { injectors, other cutters } \\
\text { with syringe, bistoury, } \\
\text { lamina-lamella, glass } \\
\text { pasteur pipette, other } \\
\text { broken glasses, etc. }\end{array}$ \\
\hline
\end{tabular}

* European Union European Waste Catalogue Code Numbers

“The Regulation for Medical Waste Control” (22 June 2005/25883). Table 1 Part I [1] 


\begin{tabular}{|l|l|}
\hline $\begin{array}{l}\text { Wastes originated from health care } \\
\text { organizations }\end{array}$ & $\begin{array}{l}\text { European Union European Waste Catalogue Code } \\
\text { Numbers }\end{array}$ \\
\hline Household Wastes & 200301 \\
\hline Packaging Wastes & $150101,150102,150104,150105,150106,150107$ \\
\hline Infectious Wastes & 180103,180202 \\
\hline Pathogenic Wastes & 180201 \\
\hline Sharp Wastes & 180101,180201 \\
\hline Hazardous Wastes & $180106,180108,180110,180205,180207$ \\
\hline
\end{tabular}

Table 1. Part II, (2001/118/EC) [12]

\subsection{Damages caused by medical waste}

According to the U.S. Ocean Dumping Act which was promulgated in 1972 for the prohibition of intentional hazardous waste disposal into the sea, the penalties can be prison sentence for 5 years and/or pecuniary punishment up to $\$ 125,000$ for civil violations as well as up to $\$ 250,000$ for criminal offences. Obviously, this falls short of preventing or discouraging the offenders from polluting the sea with medical wastes, leaving used materials and other hazardous wastes which pose a serious threat against public and environmental health. [13]

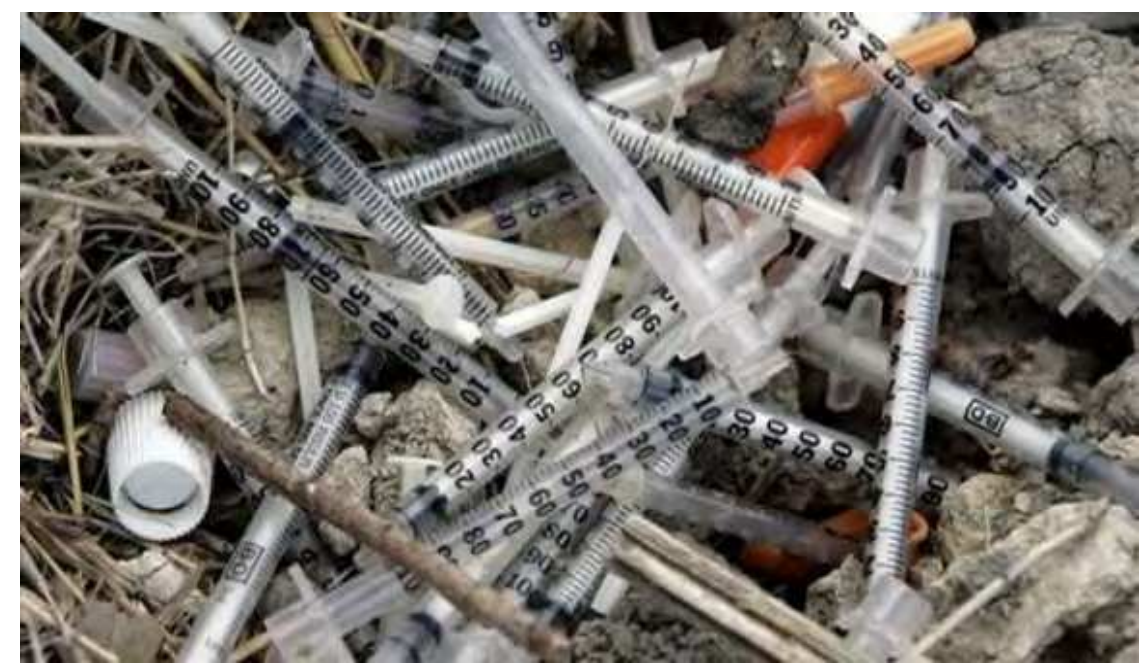

Pic. 1. Picture had taken from America's Ocean Dumping Act [13]

Unless the medical wastes are made ineffective in an appropriate manner during their collection, anyone present at that time is open to plausible risks Medical wastes are left in empty places without any processing in some countries. Public health is threatened by viruses unless they are destroyed by animals and ground waters.

Doctors and nurses who work at the premises which produce medical waste as a result of their activities constitute the groups at risk as they are in touch with the patients' blood and body liquids. 


\subsection{Medical waste risk group}

Due to unsatisfactory medical waste managements, certain groups are open to risk or prone to threat:

- Doctors, nurses, and other healthcare personnel

- Those who attend in the premises which produce infectious waste, such as patients, and hospital attendants,

- Those who work at the waste processing establishments

- Scavengers that feed on waste yards or non-isolated collection points

Children who are potentially in touch with hazardous waste, used materials, etc. [2]

\section{Accidents caused by sharp materials}

Medical wastes may comprise pathogenic viruses. As a result of inappropriate collection, those viruses may cause infection through open wounds on the body, or, any other ways on the skin which are not deep but with a high level contamination, such as mucous membrane and respiratory passage. Medical wastes should be collected in the bags with the biohazard logo separate from household wastes so that viruses do not threat human health as a result of simple mistakes.

The Table 2 shows the infection types, how they infect and sample causative organisms. The infection types caused by blood and other body liquids (saliva-mucus, urine, tears, etc.) are clearly indicated. There are necessary precautions to stop the spreading of infection in hospitals, to protect people from the infections stemming from the patients during the treatment process.

\begin{tabular}{|c|c|c|}
\hline Type of infection & Examples of causative organisms & Transmission vehicles \\
\hline Gastroenteric infections & $\begin{array}{l}\text { Enterobacteria, e.g. Salmonella, Shigella spp:; } \\
\text { Vibrio cholerae; helminths }\end{array}$ & Faeces and/or vomit. \\
\hline Respiratory infections & $\begin{array}{l}\text { Mycobacterium tuberculosis, measles virus; } \\
\text { Streptococcus pneumoniae }\end{array}$ & Inhaled secretions; saliva \\
\hline Ocular infection & Herpesvirus & Eye secretions \\
\hline Genital infections & Neisseria gonorrhoeae, herpesvirus & Genital secretions \\
\hline Skin infections & Streptococcus spp. & Pus \\
\hline Anthrax & Bacillus anthracis & Skin secretions \\
\hline Meningitis & Neisseria meningitidis & Cerebrospinal fluid \\
\hline $\begin{array}{l}\text { Acquired immunodeficiency } \\
\text { syndrome (AIDS) }\end{array}$ & Human immunodeficiency virus (HIV) & Blood, sexual secretions \\
\hline $\begin{array}{l}\text { Haemorrhagic fevers } \\
\text { Septicaemia }\end{array}$ & $\begin{array}{l}\text { Junin, Lassa, Ebola, and Marburg viruses } \\
\text { Staphylococcus spp. }\end{array}$ & $\begin{array}{l}\text { All bloody products and secretions } \\
\text { Blood }\end{array}$ \\
\hline Bacteraemia & $\begin{array}{l}\text { Coagulase-negative Staphylococcus spp: } \\
\text { Staphylococcus aureus; Enterobacter. } \\
\text { Enterococcus, Klebsiella, and } \\
\text { Streptococcus spp. }\end{array}$ & \\
\hline Candidaemia & Candida albicans & Blood \\
\hline Viral hepatitis A & Hepatitis A virus & Faeces \\
\hline Viral hepatitis $B$ and $C$ & Hepatitis $B$ and $C$ viruses & Blood and body fluids \\
\hline
\end{tabular}

Table 2. Examples of infections caused by exposure to health-care wastes, causative organisms, and transmission vehicles, Report of a WHO Study Waste from health-care activities [14] 
There are chiefly four viral diseases in case of any contact with patients' blood and contaminated body liquids. Those are HIV, Hepatitis B (HIB), Hepatitis C (HCV) and Hepatitis D (HDV) viruses. In the chapter published by WHO, Table 3 shows the number of people who are injured by the sharps among those who work at the waste management and in the U.S. hospitals and the number of HBW through injuries. The HBV infection can easily catch through those who are once exposed to blood and other infectious blood liquids and tissues.

\begin{tabular}{lcc}
\hline Professional category & $\begin{array}{l}\text { Annual number } \\
\text { of people injured } \\
\text { by sharps }\end{array}$ & $\begin{array}{l}\text { Annual number of } \\
\text { HBV infections } \\
\text { caused by injury }\end{array}$ \\
\hline Nurses & & \\
$\quad$ in hospital & $17700-22200$ & $56-96$ \\
$\quad$ outside hospital & $28000-48000$ & $26-45$ \\
Hospital laboratpry workers & $800-7500$ & $2-15$ \\
Hospital housekeepers & $11700-45300$ & $23-91$ \\
Hospital technicians & 12200 & 24 \\
Physicians and dentists in hospital & $100-400$ & $<1$ \\
Physicians outside hospital & $500-1700$ & $1-3$ \\
Dentists outside hospital & $100-300$ & $<1$ \\
Dental assistants outside hospital & $2600-3900$ & $5-8$ \\
Emergency medical personnel (outside hospital) & 12000 & 24 \\
Waste workers (outside hospital) & $500-7300$ & $1-15$ \\
\hline
\end{tabular}

Table 3. Viral hepatitis B infections caused by occupational injuries from sharps (USA) ${ }^{[8]}$

The risk of contamination increases as a result of inappropriate storage; unless the living creatures who share the same habitat, such as cats, dogs, birds, flies, mice and insects are kept far away from those areas, they can conduct microbiological pathogens and infect humans. An inappropriate medical waste storage system results in the expanding of pathogenic viruses and the transformation of medical waste into an unhealthy environmental problem. In some countries, medical wastes are collected together with household wastes; this gives rise to unhealthy scenes with which street animals can easily get in contact as it can be seen in the following pictures. 

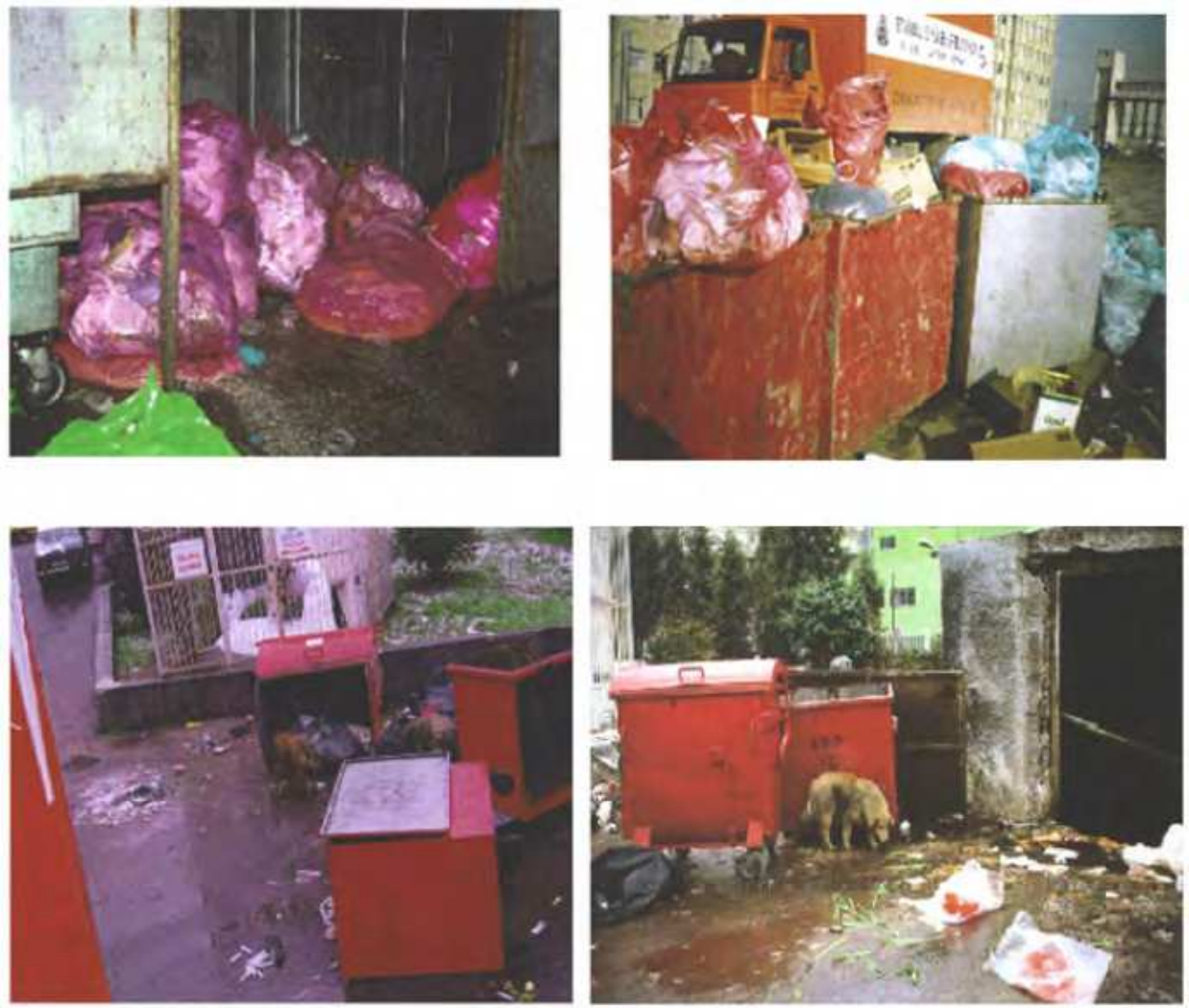

Pic. 2. (Picture had taken in 1995) Medical Waste Management in the Hazardous Waste Group, the Report of the Deputy Chair of the Environment Commission of the Grand National Assembly of Turkey [15]

The instructions published in different countries suggest that especially sharp wastes should be conserved in plastic boxes instead of bags. As every country has different application criteria, the entities which produce the waste are notified about necessary precautions by the relevant units.

As it could be seen below, sharp materials are put in plastic bags, which in turn, pose a big threat for the environment and human life because they can contact directly, with patient body liquids and easily spread viruses and pathogens as a result of this contact. As it is obvious in the picture below, syringe, sharp apparatuses are put into inappropriate bags, usually plastic bags is preferred and those bags could be easily torn during their collection or removal and they poese a huge threat for the environment. 

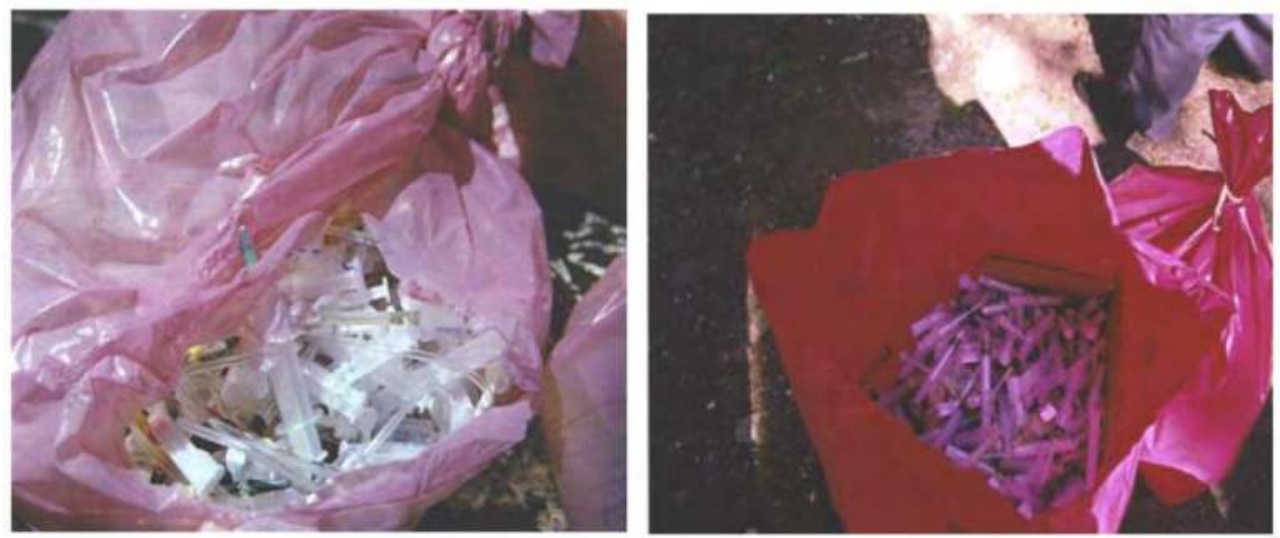

Pic. 3. Medical Waste Management in the Hazardous Waste Group, the Report of the Deputy Chair of the Environment Commission of the Grand National Assembly of Turkey [15]

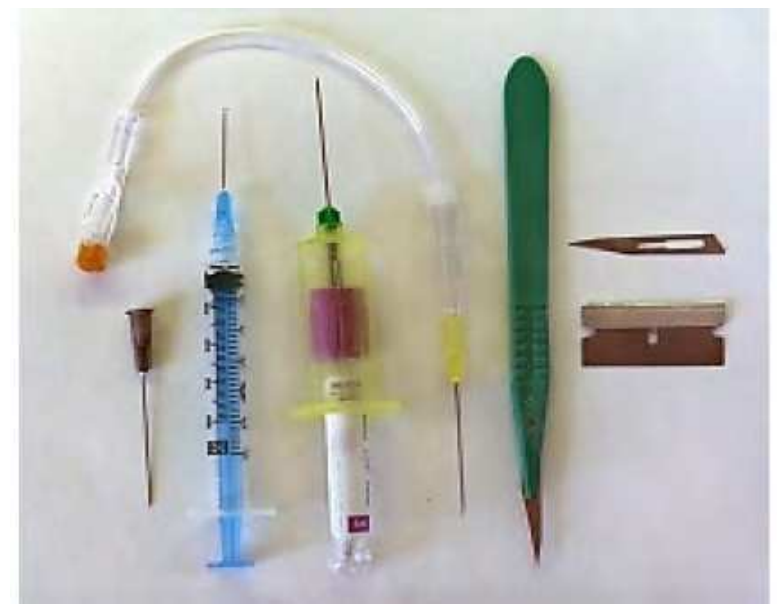

Pic. 4. Sharp objects [15]

Sharp objects should be conserved in the hard surface plastic boxes after they are used. As it can be seen in the Picture 5-6, instead of the bags with the possibility to be torn or punctured during transmission, it is considered more preferable to use plastic boxes which can not be torn or punctured. 


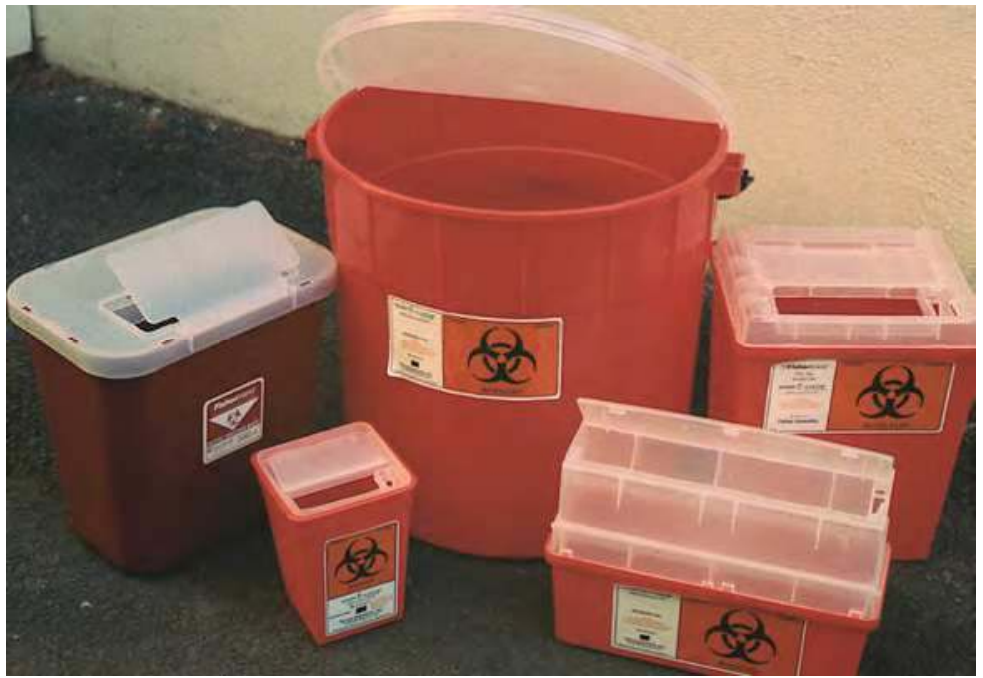

Pic. 5. Princeton University (2008), “Laboratory Waste Streams” picture available at [Ref, 16]

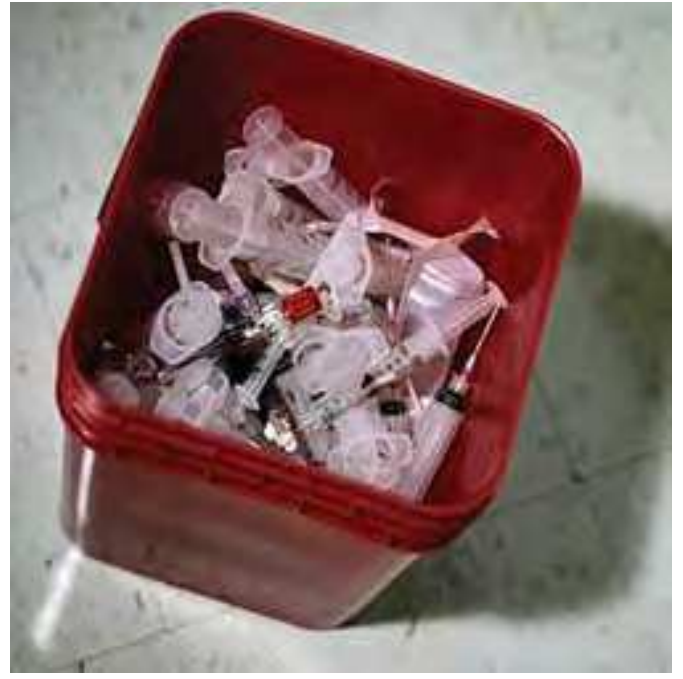

Pic. 6. Hazardous Waste Management Plan (HWMP), (1990), California Country of El Dorado, available at [Ref 17]

\subsection{Methods of treating hazardous medical waste}

There are tons of medical wastes collected from hospitals. There are also different methods applied by certain institutions, municipalities or firms which work in compliance with the related authorities to treat this hazardous medical waste.. Money spent for the application of such methods is the main criteria in choosing these methods. In addition, in some countries, medical waste is disposed in an environment-friendly manner. 
- Containment processes

i. Landfilling in municipal disposal sites

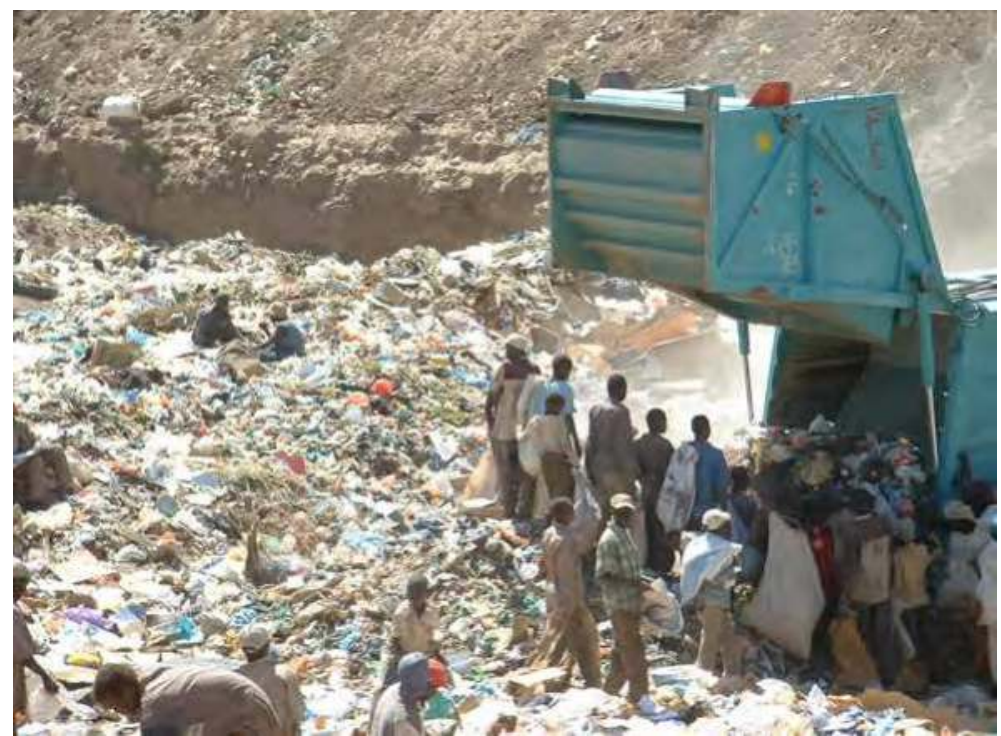

Pic. 7. UNEP (United Nations Environment Programme), (2007), “Waste management is problematic throughout Sudan" [18]

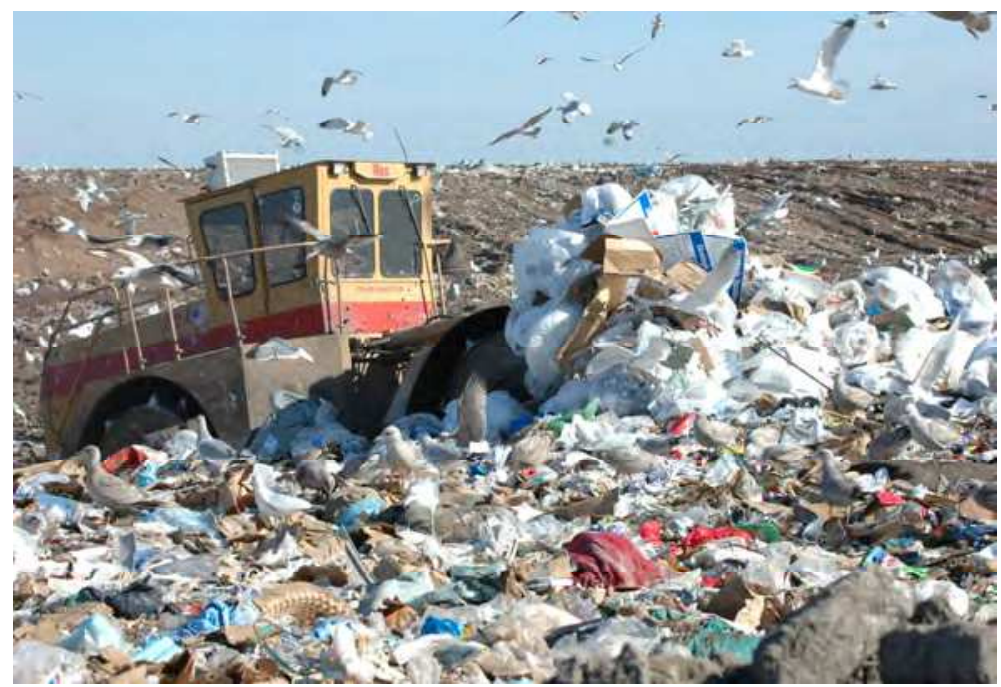

Pic. 8. UNEP (United Nations Environment Programme), (2007), “Waste management is problematic throughout Sudan" [18] 
Unsanitary disposal which gives rise to environmental pollution seriously threatens both living creatures and human health. Considering the damages which come out of inappropriate medical waste storage, it is prohibited to bury infectious wastes in regular storage areas, in compliance with European Union Directive 99/31/EC. [19] In the nonmember states, this application causes serious harms against environment and human health. Viruses contaminated in the buried medical wastes threaten human health through the conductor insects and the ground waters being mixed up with drinkable water. It is also inevitable that those who share the same living area with animals and plants infect humans through food chain. (Pic 9) The medical wastes buried without any processing or dumped in an uncontrolled way give damages to the environment as potential microbe nidus.

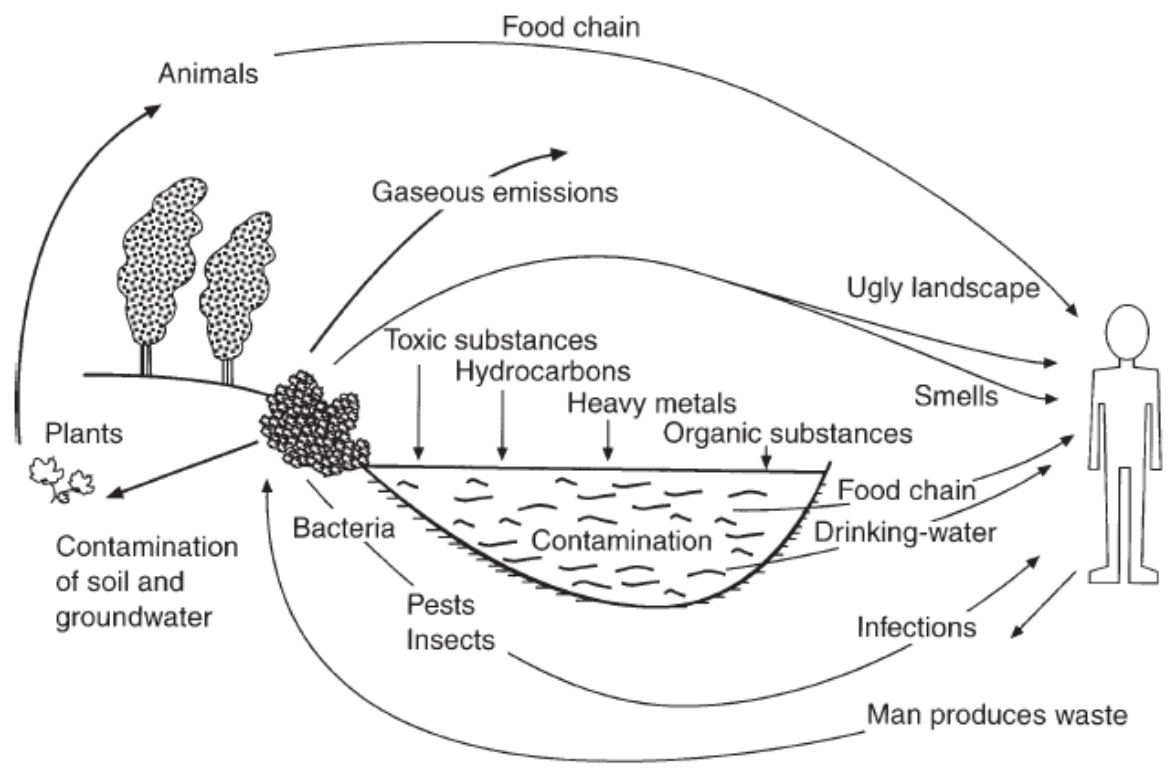

Pic. 9. [20]

Medical wastes should be filled on an impervious land without being pressed. It is required to cover the waste over after daily storage, and this should be covered by shielding with $30 \mathrm{~cm}$ earth. In doing so, sanitary waste storage becomes applicable between the impervious land and the upper clay lump ground. Any living creature will not bee able to reach at the medical waste covered by earth, and it will be prevented for surface waters to penetrate. This method which is prohibited in European countries is still being preferred by some countries since it is the most economic method in comparison with other disposal methods. Sanitary medical waste storage method is presented in the Picture -12-. For sanitary storage, the ground should be first made impervious. It is necessary to prevent the leakage stemming from the buried medical waste. (Drainage coefficient is available in the directives of countries. Any drainage system should not be built smaller than $\mathrm{k}=1 \times 10^{-4}$.) 

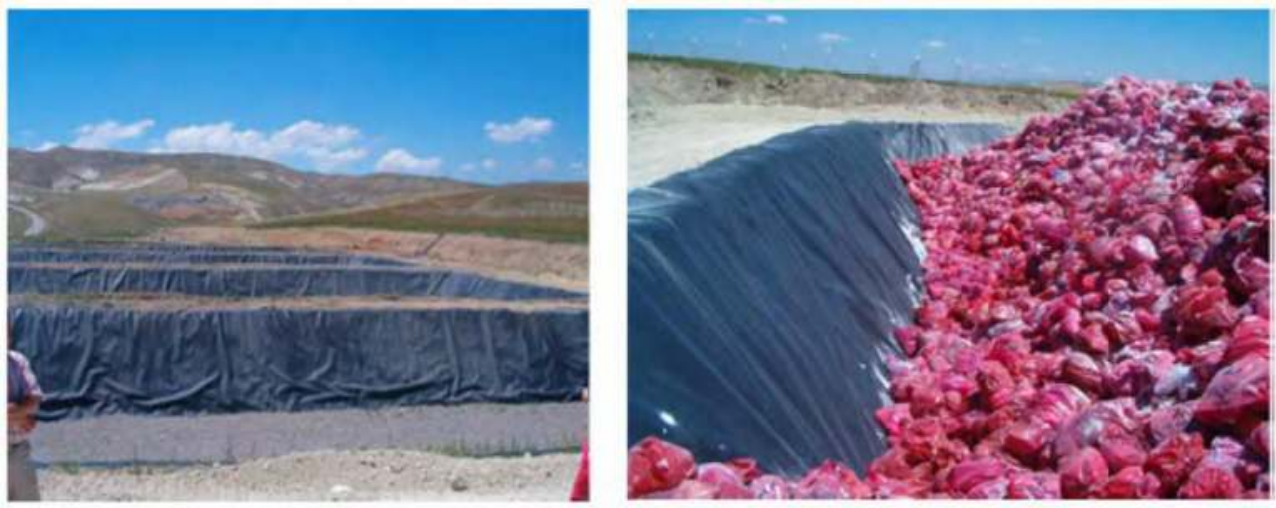

Pic. 10. Medical Waste Management in the Hazardous Waste Group, the Report of the Deputy Chair of the Environment Commission of the Grand National Assembly of Turkey [15]

4.2 Incineration technologies (medical waste incineration)

While disposal of medical waste through incineration is one of the most reliable technologies, it costs extremely high to establish a plant which will harm the environment at a minimum level. The first investment granted for incineration systems and the cost of plants are much higher than other technologies.

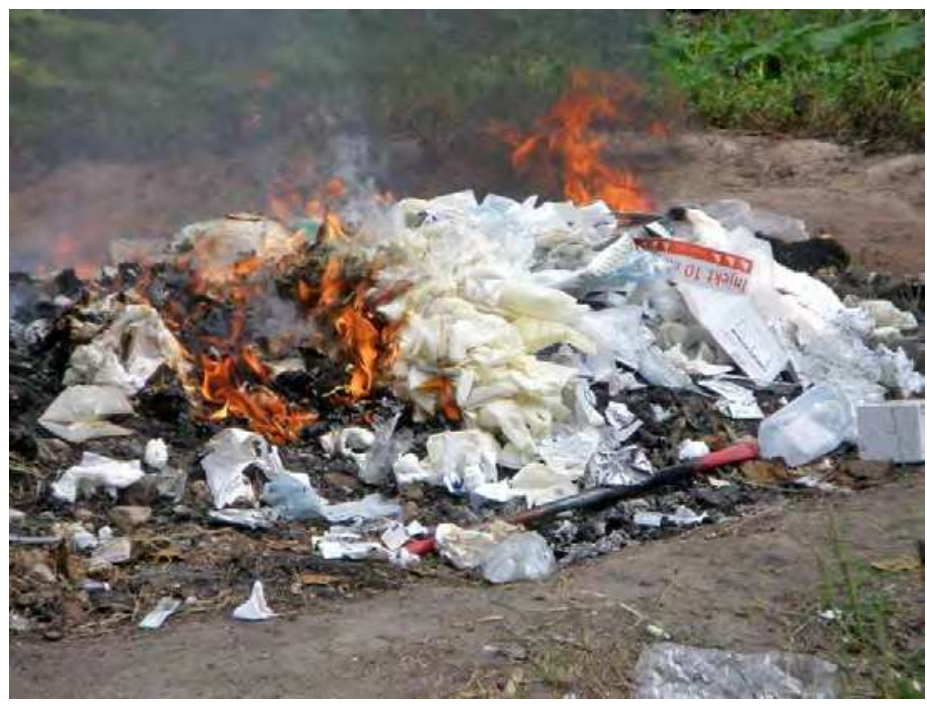

Pic. 11. "Open burning of medical waste may not destroy pathogens and produces considerable toxic emissions" (Batterman S. 2008)[21]

If medical wastes are incinerated as in the Picture 13, they give much more serious damages to the environment. It is especially necessary for medical wastes not to comprise materials 
with heavy metals, radioactive wastes, broken thermometers or other materials with mercury and cadmium.

The flue gas emission values should be definitely kept under control because the gas which appears during the incineration operation causes serious damages against environment and penetrates into the atmosphere that we breath.

The carbon monoxide which appears at hight levels in the flue gas emission values indicates the incineration operation is cariied out at low temperatures. The unburned hydrocarbons, dioxin and furans, volatile heavy metals and their compunds, and other gases such as TOK, $\mathrm{HCI}, \mathrm{HF}, \mathrm{SO} 2$, NOX comes out of this operation. Those gases should be exhausted to the atmosphere through the flue after they are falled under the determined standards. Those flue values are declared by the relevant authorities of countries; and those institutions are auditting the plants which dispose medical wastes with a granted license. Emission guidelines for "hospital/medical/infectious waste" incinerators below Table 4 .

\begin{tabular}{|c|c|c|c|}
\hline Pollutant & $\begin{array}{l}\text { Small incinerator } \\
\text { ( } \leq 91 \mathrm{~kg} / \mathrm{hour} \text { ) }\end{array}$ & $\begin{array}{l}\text { Medium incinerator } \\
\text { (>91-227 kg/hour) }\end{array}$ & $\begin{array}{l}\text { Large incinerator } \\
\text { ( }>227 \mathrm{~kg} / \mathrm{hour} \text { ) }\end{array}$ \\
\hline \multicolumn{4}{|c|}{ A. Emission limits for new incinerators (construction after June 1996) } \\
\hline Particulate matter & $115 \mathrm{mg} / \mathrm{m}^{3}$ & $69 \mathrm{mg} / \mathrm{m}^{3}$ & \\
\hline Carbon monoxide (CO) & 40 ppmv & 40 pprnv & \\
\hline Dioxins/furans & $\begin{array}{c}125 \mathrm{ng} / \mathrm{m}^{3} \text { total } \\
\mathrm{CCD} / \mathrm{CDF} \text { or } \\
2.3 \mathrm{ng} / \mathrm{m}^{3} \text { TEO }\end{array}$ & $\begin{array}{c}125 \mathrm{ng} / \mathrm{m}^{3} \text { total } \\
\mathrm{CCD} / \mathrm{CDF} \text { or } \\
2.3 \mathrm{ng} / \mathrm{m}^{3} \text { TEQ }\end{array}$ & $\begin{array}{l}125 \mathrm{ng} / \mathrm{m}^{3} \text { total } \\
\mathrm{CCD} / \mathrm{CDF} \text { or } \\
2.3 \mathrm{ng} / \mathrm{m}^{3} \text { TEO }\end{array}$ \\
\hline Hydrogen chloride $(\mathrm{HCl})$ & $\begin{array}{l}100 \text { ppmv or } \\
93 \% \text { reduction }\end{array}$ & $\begin{array}{l}100 \mathrm{ppmv} \text { or } \\
93 \% \text { reduction }\end{array}$ & $\begin{array}{l}100 \text { ppmv or } \\
93 \% \text { reduction }\end{array}$ \\
\hline Sulfur dioxide $\left(\mathrm{SO}_{2}\right)$ & $55 \mathrm{ppmv}$ & $55 \mathrm{ppmv}$ & 55 pprnv \\
\hline Nitrogen oxides & 250 ppmv & $250 \mathrm{ppmv}$ & $250 \mathrm{ppmv}$ \\
\hline Lead & $\begin{array}{l}1.2 \mathrm{mg} / \mathrm{m}^{3} \text { or } \\
70 \% \text { reduction }\end{array}$ & $\begin{array}{l}1.2 \mathrm{mg} / \mathrm{m}^{3} \text { or } \\
70 \% \text { reduction }\end{array}$ & $\begin{array}{l}1.2 \mathrm{mg} / \mathrm{m}^{3} \text { or } \\
70 \% \text { reduction }\end{array}$ \\
\hline Cadmium & $\begin{array}{l}0.16 \mathrm{mg} / \mathrm{m}^{3} \text { or } \\
65 \% \text { reduction }\end{array}$ & $\begin{array}{l}0.16 \mathrm{mg}^{\prime} \mathrm{m}^{3} \text { or } \\
65 \% \text { reduction }\end{array}$ & $\begin{array}{l}0.16 \mathrm{mg} / \mathrm{m}^{3} \text { or } \\
65 \% \text { reduction }\end{array}$ \\
\hline Mercury & $\begin{array}{l}0.55 \mathrm{mg} / \mathrm{m}^{3} \text { or } \\
85 \% \text { reduction }\end{array}$ & $\begin{array}{l}0.55 \mathrm{mg} / \mathrm{m}^{3} \text { or } \\
85 \% \text { reduction }\end{array}$ & $\begin{array}{l}0.55 \mathrm{mg} / \mathrm{m}^{3} \text { or } \\
85 \% \text { reduction }\end{array}$ \\
\hline
\end{tabular}

Sources: Safe Management of Wastes from Health-care Activities' which was published by WHO in 1999 [8]

Table 4.

Whille the post-incineration energy can be used as heating energy in winter times, it can also be used in the power generation in summers. While the energy recovery plants which convert those wastes into energy serve the disposal of medical wastes which threaten human life, it is for good that those wastes are being recovered as power or heat necessary for human life. In developed countries, the double stage systems are used, the most common of which is Controlled-Air Incinerators.

As the most common medical waste incineration (MWI) system, Controlled-air incineration is predominantly set up at health care centers and other medical institutions. It is also known as starved-air incineration, two-stage incineration, or modular combustion. A typical schematic diagram of a controlled air unit is represented in the Picture 12 
There are mainly two stages of the waste combustion in this mechanism. In the first stage, waste is fed into the primary, or lower, combustion chamber, which is operated with less than the stoichiometric amount of air required for combustion. Combustion air which is also called as primary or under fire air enters the primary chamber from beneath the incinerator hearth (below the burning bed of waste). In the primary (starved-air) chamber, the low airto-fuel ratio dries and facilitates

Volatilization of the waste and most of the residual carbon in the ash burns. Under these circumstances, combustion gas temperatures are relatively low (760 to $980^{\circ} \mathrm{C}[1,400$ to $\left.\left.1,800^{\circ} \mathrm{F}\right]\right)$.

While the organic substances in the medical waste are being burned, the pathogenic organisms are also disposed. After the incineration the medical waste decrease by $95 \%$ in volume, and by $80 \%$ in mass. The duration of the medical wastes held in the incineration unit varies in relation to the types of systems.

The post-incineration (volatile) gases accompanied with excess air are sent to the second stage so that they can be burned completely. Secondary chamber temperatures are higher than primary chamber temperatures - at least from 980 to $1,095^{\circ} \mathrm{C}\left(1,800\right.$ to $\left.2,000^{\circ} \mathrm{F}\right)$. These values are changeable, sometimes needed to increase, according to the heating value and moisture content of the waste through auxiliary burners located at the entrance to the secondary (upper) chamber to reach at the desired temperatures. This operation enables the demolition of organic toxic substances such as dioxin and furan. There might be a considerable between the minimum and the maximum waste feed capacities for controlled air incinerators. For example, it ranges from about 0.6 to $50 \mathrm{~kg} / \mathrm{min}(75$ to $6,500 \mathrm{lb} / \mathrm{hr})$ at an assumed fuel heating value of $19,700 \mathrm{~kJ} / \mathrm{kg}$ [8,500 Btu/lb]. On the other hand, lower heating value wastes require a higher degree throughput capacity because feed capacities are limited by primary. The unit size and options purchased are the determining factors on whether waste feed and ash removal will be carried out manually or automatically. [22]

The post-incineration (volatile) gases accompanied with excess air are sent to the second stage so that they can be burned completely.

Secondary chamber temperatures are higher than primary chamber temperatures - at least from 980 to $1,095^{\circ} \mathrm{C}\left(1,800\right.$ to $\left.2,000^{\circ} \mathrm{F}\right)$. These values are changeable, sometimes needed to increase, according to the heating value and moisture content of the waste through auxiliary burners located at the entrance to the secondary (upper) chamber to reach at the desired temperatures. This operation enables the demolition of organic toxic substances such as dioxin and furan.

There might be a considerable between the minimum and the maximum waste feed capacities for controlled air incinerators. For example, it ranges from about 0.6 to $50 \mathrm{~kg} / \mathrm{min}$ (75 to $6,500 \mathrm{lb} / \mathrm{hr}$ ) at an assumed fuel heating value of $19,700 \mathrm{~kJ} / \mathrm{kg}[8,500 \mathrm{Btu} / \mathrm{lb}]$. On the other hand, lower heating value wastes require a higher degree throughput capacity because feed capacities are limited by primary. The unit size and options purchased are the determining factors on whether waste feed and ash removal will be carried out manually or automatically. [11]

Apart from some advantages, the incineration systems with their various types have some disadvantages. For those negativities, the advanced countries develop some solutions which get rid of the burning smell with flue infiltration at high level costs. If the incinerator 


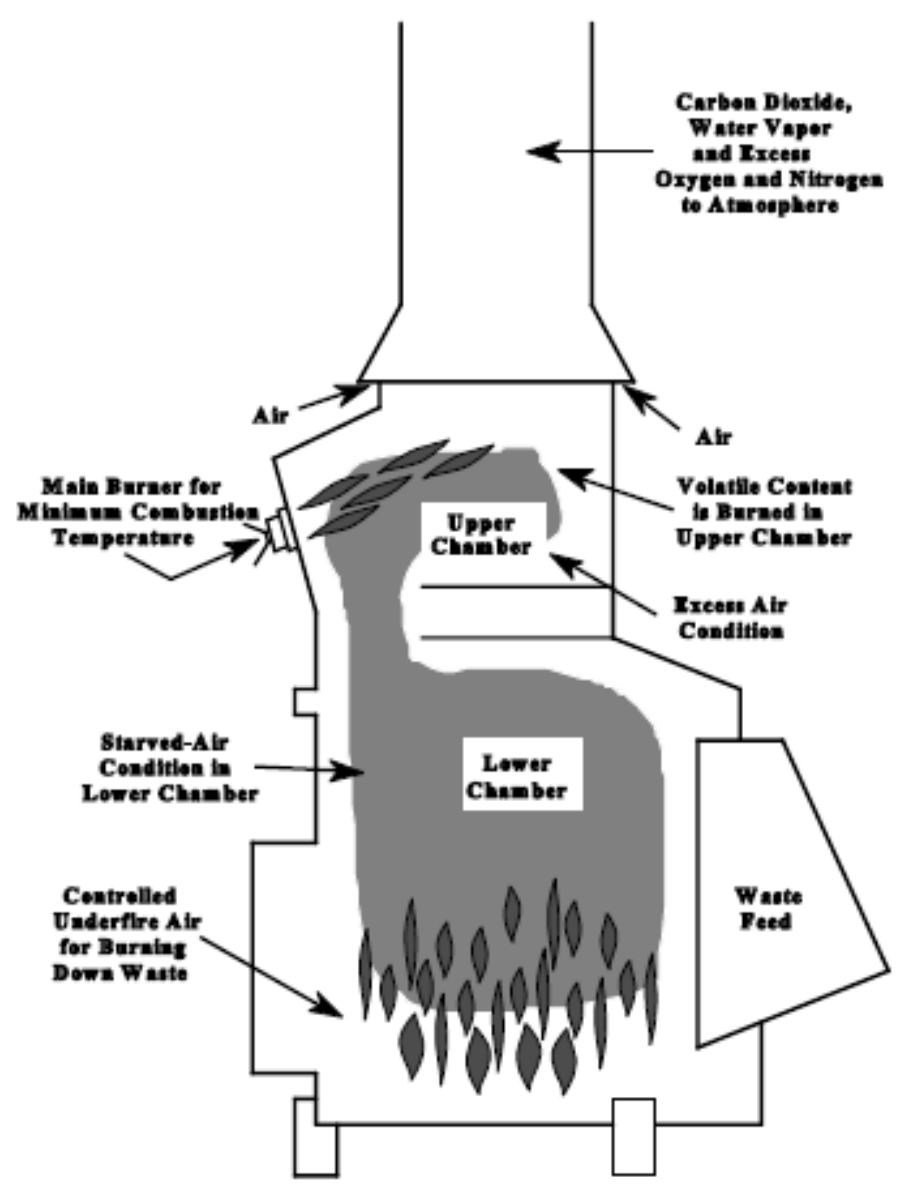

Pic. 12. Incineration Solid Waste Disposal (1995), [22].

operates at lower heat, it produces 8-10 times more dioxin and furans than any normal operation. In other words, dioxins and furans are formed at the maximum level when the incinerator works at the lowest temperature $\left(200-450^{\circ} \mathrm{C}\right)$. For this reason, the ambient temperature is increased by using supplemental fuels, therefore, the risk is eliminated. [23] 

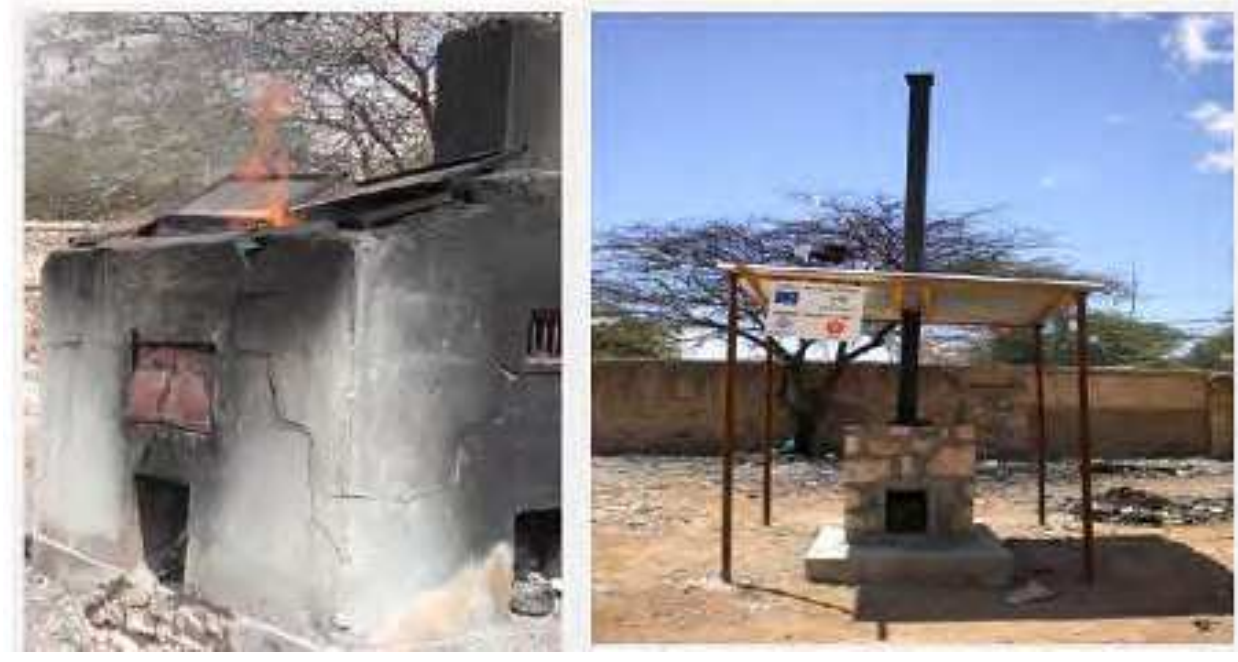

Pic. 13. 'De Montfort' incinerators

'De Montfort' incinerators are systems widely used by underdeveloped countries today. It is first created by the De Montfort University Innovation Technology Center (Leicester, UK) whose name is now Applied Sustainable Technology Group in order to provide a cheap but effective healthcare wastes incinerators for developing or underdeveloped countries. It would meet the criteria of a temperature of above $800^{\circ} \mathrm{C}$ with a residence time of over 1 second. [23]

There are considerable amount of studies which show that the implementation of De Montfort incinerators are widely used in certain countries with the low income per capita, such as Kenya, Tanzania, and India. [3]

- Kenya: The studies indicate that the $55 \%$ of the 44 De Montfort type incinerators which were constructed in 2002 were in intermittent or regular use. It is also determined that only 1 of 14 sites in which tests and interviews were conducted had an operator with 'near to adequate' skills,[24]. While nearly $40 \%$ of health facility managers demonstrated any level of commitment, many technical defects in the equipment and inappropriate operation of incinerators are other results of the observations. [25]

- Tanzania: All 'De Montfort' type incinerators which were constructed in 2001 and 2003 were in use at the time of study of which less than $40 \%$ had trained operators, $70 \%$ had low smoke disturbance and $60 \%$ had safe ash disposal [24]).

- India: HCWH made a research on eight 'De Montfort' incinerators at hospitals in India which are mostly 1 or 2 years old (2002). The findings of this study can be stated as follows: visible smoke from the stack; smoke emission from the chamber door and air inlets; commingling of sharps and non-infectious waste, despite some source segregation; large quantities of unburned materials (sometimes plastics, syringes, glass, paper and gauze) in the ash; deficient ash disposal practices; siting in all cases near populated areas (e.g., playground, orphanage, hospital staff quarters, a primary school, town center) and a lack of operator training. [26] 


\subsection{Emissions and their monitoring to the incineration technologies}

The flue values are really significant for incineration systems. Referring to environmental effects, incinerators can produce toxic emissions such as carbon monoxide (CO), dioxins (polychlorinated dibenzo-para-dioxins or PCDDs), and furans (polychlorinated dibenzofurans or PCDFs).

- Hospital wastes contain a considerable amount of plastic substances. $15-20 \%$ of those wastes are PVCs. It is also possible to find approximately 9-10\% PVC in infectious wastes. The equipments with PVC which are used in medical centers are IV bags, IV tubes, blood bags, endotracheal tubes, bed coverings, and oxygen tents.

Waste segregation is extremely important for preventing the incineration of PVC (IVs, etc.) waste. In case of any presence of chloric substances such as PVS in the medical waste, this causes the formation of some volatile organic substances as a result of combustion, such as dioxins and furans. The materials with PE or PET are much more preferable than those with PVC.

- Controlling whether the incinerator is constructed in accordance with the recommended dimensions, using appropriate materials, whether it is functioning properly, and keeping the chimney clear of excessive soot.

The incinerators should be constructed in compliance with the standards determined by the relevant authorities of countries. Appropriate material tests and regular flue controls are necessary.

- Ensuring that the preheating of incinerator functions adequately, and that supplementary fuel is added whenever necessary.

Temperature degree should not be ignored. The gases coming out at low temperature constitutes a threat against human health.

- $\quad$ Adopting rigid quality control measures.

It is very important to do routine checks regularly and follow the rules.

In addition to all these instructions, it is also necessary to install a gauge temperature degree on the chimney in order to maintain the temperature during the operation. Smoke levels, loading rates, usage of fuel and the incinerated waste type are other parameters to be rigorously monitored and recorded. If it is impossible to install a gauge, it might be helpful to follow a visual guide in order to maintain the temperature.[26]

Other data to be carefully recorded during the combustion operation: following the temperature of the incinerator, smell degree, the amount of the medical waste which is fed, the amount of the medical waste which is disposed at the end of the day, the amount of the fuel used.

Finally It draws attention towards different systems that the establishment and operation of the incineration technology plants cost very high and the rules and standards are becoming increasingly difficult. The unlimited growth in the residential areas along with the increase in the world population make things difficult for the operators in terms of finding appropriate spaces practically. 
The greatest sanction which is impossible to ignore comes from the rule maker authorities. As it can be seen in the publication, namely 'Safe Management of Wastes from Health-care Activities' which was published by WHO in 1999 (Table 4) [8], Dioxins/furans 2.3 ng was declared as TEQ.

In the European Union Directive No. 2000/76/EC [27] which was published on 4 December 2000 , the emission values in the incineration plants was determined as $0.1 \mathrm{ng}$ TEQ/m3 for dioxins and furans.

\begin{tabular}{|c|c|c|c|}
\hline Emission & $\begin{array}{l}\text { Daily average } \\
\left(\mathrm{mg} / \mathrm{m}^{3}\right)^{0}\end{array}$ & $\begin{array}{l}\text { Hourly average } \\
\left(\mathrm{mg} / \mathrm{m}^{3}\right)^{\mathrm{a}}\end{array}$ & $\begin{array}{l}\text { 4-hour average } \\
\left(\mathrm{mg} / \mathrm{m}^{3}\right)^{=}\end{array}$ \\
\hline Total dust & 5 & 10 & - \\
\hline Total organic carbon & 5 & 10 & - \\
\hline Chlorine compounds & 5 & 10 & - \\
\hline Fluorine compounds & 1 & 2 & - \\
\hline Sulfur axides as $\mathrm{SO}_{2}$ & 25 & 50 & - \\
\hline Nitrogen oxides as $\mathrm{NO}_{2}$ & 100 & 200 & - \\
\hline Carbon monoxide & 50 & 100 & - \\
\hline Mercury & - & - & 0.05 \\
\hline Cadmium and thallium & - & - & 0.05 \\
\hline $\begin{array}{l}\text { Lead, chromium, copper, } \\
\text { and manganese }\end{array}$ & - & - & 0.5 \\
\hline Nickel and arsenic & - & - & 0.5 \\
\hline $\begin{array}{l}\text { Antimony, cobalt, } \\
\text { vanadium, and tin }\end{array}$ & - & - & 0.5 \\
\hline Dioxins and furans & - & - & 0.1 \\
\hline Oxygen content & \multicolumn{3}{|c|}{ af least $6 \%$ at any moment } \\
\hline
\end{tabular}

"Measurements made at standard temperature and pressure.

Table 5. [8] Standards for incinerator emissions in the European Union

As a result of this amendments, the new member states and the Eastern European countries had difficulties with satisfying those criteria, and some of these countries had to close plants, and the others managed to meet those criteria by making unplanned investments. [28] The lifetime for the incineration technologies is limited by 10 years and their establishment and operation is at a high cost. When we make comparison between incineration technologies and non-incineration technologies, the necessity for a considerable maintenance and investment makes non-incineration technologies more preferable.

\section{Non-incineration technologies}

Non-incineration treatment technologies can be classified based on a number of different criteria. They can be classified according to the ownership in the market share, the types of the waste of disposal, or, the purchase price of the technology. Moreover, Dr. Jorge Emmanuel and his friends' studies in 2004 [28] show another way of categorization non-incineration technologies based on the fundamental process used to decontaminate waste. 
Non-incineration Technologies are categorized in this section as follows:

i. Chemical processes

ii. Irradiative processes

iii. Biological processes

iv. Low-heat thermal processes

\subsection{Chemical processes}

Chemical disinfectants are generally used for killing microorganisms and inactivating hazardous pathogens. The chemicals used in cleaning the surfaces touched by infected patients and other patients' apparatuses in hospitals is also another method preferred by some systems for nullification of medical wastes. The disinfection process becomes more practical by supplementing a large amount of water into the chemical disinfectants; this also helps to cool mechanical equipment during the shredding, grinding, or mixing process. Those systems that prefers this method are usually used during the volumetric grinding of medical wastes. If the amount of supplemented water exceeds the defined measure, the chemical loses its effect, then it falls short of satisfying the desired level of disinfection. Among the disinfectants preferred in chemical processes are dissolved chlorine dioxide, bleach (sodium hypochlorite), peracetic acid, or dry inorganic chemicals.

Depending on the sterilization effectiveness of the chemical disinfectant to be used in the medical waste disposal, the reaction of some factors should be taken into consideration. Chemical temperature, water and $\mathrm{pH}$ values can change the disinfection effectiveness. Chlorine, ozone, formaldehyde, ethylene oxide gas, propylene oxide gas and peracetic acids can be preferred in order to support chemical disinfection. The chemical formulas of some technologies that are available on the market are sold-provided to the user in exchange with kit by the supplier firm of the technology without being exposed.

The most efficient treatment in which the chemical disinfectants are used is of liquid wastes, especially blood, urine, stools, or hospital sewage. On the other hand, there are certain limitations on the chemical disinfection processes of solid- and even highly hazardous- health-care wastes, such as microbiological cultures, sharps, etc. First of all, those types of wastes should be subject to shredding and/or milling processes. It is frequently observed that the shredder, the mostly weakest element of the treatment chain, exposes mechanical failures, or even breakdown. Therefore, the regular check-ups of those equipments are very important. Another point to take into account is the training and the protection of personnel who are supposed to use these powerful disinfectants which are themselves also hazardous. Furthermore, operational conditions should be suitable for an efficient disinfection process. Also, the disinfection should be applied to only the surface of intact solid waste. [8]

\subsubsection{Types of chemical disinfectants}

Depending on their efficiencies and functions, the type of chemical disinfectants used in the disinfection changes. Sodium hypochlorite functions in killing microorganisms which requires the shredding of the biomedical waste units, such as bags, boxes or other type of containers. For disinfection to be accomplished, there must be a reduction of $4 \log 10$ $(99.99 \%$ reduction) in the spores of B. stearothermophilus or B. subtilis. Among other 
chemicals to be used in chemical disinfection are chlorine derivatives, ozone and some enzymes. [29]

The use of hypochlorite solutions in killing microorganisms, on the other hand, first requires that the biomedical containers be subject to grinding. There must be a reduction of $4 \log 10$ ( $99.99 \%$ reduction) in the spores of B. stearothermophilus or B. subtilis where the process is completed. For example, chlorine derivatives, ozone or enzymes are some other chemicals that can be used in chemical disinfectant groups.[29]

An overview of the characteristics of the main groups of disinfectants is given in Table $6[8]$

\begin{tabular}{|c|c|c|c|c|c|c|c|}
\hline Disinfectants & $\begin{array}{l}\text { Bactericidal } \\
\text { activity }\end{array}$ & $\begin{array}{l}\text { Tuberculocidal } \\
\text { activity }\end{array}$ & $\begin{array}{l}\text { Fungicidal } \\
\text { activity }\end{array}$ & $\begin{array}{l}\text { Virucidal } \\
\text { activity }\end{array}$ & $\begin{array}{l}\text { Sporicidal } \\
\text { activity }\end{array}$ & $\begin{array}{l}\text { Local } \\
\text { human } \\
\text { toxicity }\end{array}$ & Applications \\
\hline Alcohol & Very active & Very active & Very active & Very active & Not active & Moderate & $\begin{array}{l}\text { - Skin antisepsis } \\
\text { - Disinfection of } \\
\text { small surfaces }\end{array}$ \\
\hline Chlorhexidine & $\begin{array}{l}\text { Less active } \\
\text { against Gram- } \\
\text { negative bacilli }\end{array}$ & Not active & Less active & Not active & Not active & Law & $\begin{array}{l}\text { - Skin and wound } \\
\text { antisepsis }\end{array}$ \\
\hline $\begin{array}{l}\text { Chlorine } \\
\text { compounds } \\
\text { (chloramine, } \\
\text { hypochlorite) }\end{array}$ & Very active & Active & Active & Very active & Less active & Moderate & $\begin{array}{l}\text { - Skin and wound } \\
\text { antisepsis } \\
\text { - Water treatment } \\
\text { - Surface } \\
\text { disinfection }\end{array}$ \\
\hline Formaldehyde & Very active & Very active & Very active & Very active & Less active & High & $\begin{array}{l}\text { - Disinfection of } \\
\text { inanimate objects } \\
\text { and surfaces }\end{array}$ \\
\hline Glutaraldehyde & Very active & Very active & Very active & Very active & Very active & High & $\begin{array}{l}\text { - Disinfection of } \\
\text { inanimate objects }\end{array}$ \\
\hline $\begin{array}{l}\text { Hydrogen } \\
\text { peroxide }\end{array}$ & $\begin{array}{l}\text { Less active } \\
\text { against } \\
\text { staphylococci } \\
\text { and enterococci }\end{array}$ & Active & Active & Active & Less active & Low & - Wound antisepsis \\
\hline Iodophore & Active & Active & Less active & Active & Not active & Moderate & $\begin{array}{l}\text { - Skin and wound } \\
\text { antisepsis }\end{array}$ \\
\hline Peracetic acid & Very active & Active & Active & Active & Active & High & $\begin{array}{l}\text { - Disinfection of } \\
\text { inanimate objects }\end{array}$ \\
\hline $\begin{array}{l}\text { Phenolic } \\
\text { compounds }\end{array}$ & Very active & Very active & Very active & Less active & Not active & High & $\begin{array}{l}\text { Disinfection of } \\
\text { inanimate objects } \\
\text { and surfaces }\end{array}$ \\
\hline $\begin{array}{l}\text { Quaternary } \\
\text { ammonium } \\
\text { compounds }\end{array}$ & $\begin{array}{l}\text { Less active } \\
\text { against Gram- } \\
\text { negative bacillt }\end{array}$ & Not active: & Less active & Less active & Not active & Low & $\begin{array}{l}\text { - in combination } \\
\text { with other } \\
\text { compounds }\end{array}$ \\
\hline
\end{tabular}

Table 6. Characteristics of the main disinfectant groups [8]

As the World Health organization declared and can be seen in the Table 5, there are certain spaces in which disinfectants can be actively used. There is no such a chemical substance which is able to kill all kinds of microorganisms, or suitable for using in every type of medium. As a general fact, it is true that it is the primary function of disinfectants to eliminate microorganisms, or at least reduce them to a certain desired degree. However, their target varies depending on not only their effectiveness but also their corrosiveness. In this regard, it is extremely important to know which type of disinfectant is efficient on which type of medium along with the types of organisms on which they have an effect. Besides the types of chemicals mostly used for disinfection of health-care waste such as aldehydes, chlorine compounds, ammonium salts, and phenolic compounds, ethylene oxide 
is used in hospitals for the disinfection of the substances of which forms are decomposed at a high degree temperature and heat. Its use is no longer recommended since the handling of ethylene may give rise to significant hazards, as another factor affecting the use of such chemicals in disinfection, although it may still be used in some countries. Under normal circumstances, disposal necessitates single use only. Yet such chemicals are used in some countries intentionally despite their hazards against human health because of their costeffectiveness. Therefore we can conclude that chemical processes are not sufficient methods in the medical waste disposal by themselves.

\subsection{Irradiative processes}

Irradiation technology is mainly based on electron beam system. In other words, irradiation technologies comprise Cobalt-60, or ultraviolet beams (UV), or electron beams. This technology works through a process in which electromagnetic radiation extracts the electron from the nuclear orbit when it reaches at a certain energy level. The most significant difference of this technology from microwaves is its extraction of electron from the orbit. The system which completely functions through computer software control is a design of high technology. After the hazardous wastes collected from hospitals are subject to a process through this technology, they become non-noxious- household wastes. The medical wastes become unrecognizable after this processing. They completely lose their physical form and reduce in volume. Considering the advantages of the technology, it is not an unknown system to biomedical engineers since it has been used in cancer therapies more than 20 years. This also shows us that biomedical applications and the biomedical sphere itself are interdisciplinary.

Another advantage of the technology which should be emphasized here is its environment friendly qualities. In contrast to other incineration technologies, it does not cause any air pollution with the minimum degree of toxic emissions except for a negligible amount of ozone. Moreover, the absence of any liquid waste draws another aspect which makes it preferable. In terms of practicality, it is a technology which can be easily operated in room temperature as well as it does not require any extra consumable materials such as extra water, vapor, heat or any extra chemicals. Additionally, it has a low operating cost.

When it comes to the disadvantages of this technology, it requires a highly-organized personnel safety. Since it has a considerable capital cost to build a concrete shield, or an underground structure for the protection from radiation in terms of both thickness and infrastructure, it should be well calculated before the project. Ozone off-gas which is extracted from the exhaust after the process can be considered as another disadvantage of the system.

\subsection{Biological processes}

In the medical waste disposal technologies, not too many technologies which work on biological procedures are available on the market. The fundamental principle of this technology is to provide the medical waste disposal by destroying enzymes and organic substances. An enzyme mixture used in the system decontaminates the medical waste first, and then the sewage disposal is achieved through the extrusion of the residuum. Only few technologies has tried this method. The system which is not allowed in EU countries has 
been tested in Virginia State in the U.S.A., under the name "Bio-Converter", and mostly used in agriculture to dispose animal waste due to its capacity for large applications (10 tons/day) ${ }^{[28]}$ Biological process technologies are not widely released to the market because its feasibility are not efficient and these technology still in the research and development phase.

\subsection{Low-heat thermal processes}

First of all, the equipments designed by the low-heat thermal technologies transform the medical wastes into household (non-noxious) wastes, killing microorganisms in between $93^{\circ} \mathrm{C}$ and $177^{\circ} \mathrm{C}$. We can analyze this technology in two categories: wet heat (steam) thermal technologies and dry heat (hot air) thermal technologies.

- Low-heat thermal technologies:

i. Autoclaves

In wet heat treatment technology, steam is used, and all thanks to this, the medical waste becomes disinfected and sterilized, that is, disposed of microorganisms. This operation is completed in a pressure container, namely autoclaves. Autoclave technology equipments have been used for years in the sterilization of the materials used in hospitals. These equipments secure the sterilization with pressurized steam at high temperature. Thus, surgery sets in hospitals are being sterilized in this way, and become reusable again and again. The pressurized steam has the capacity to reach at the inmost pores, and thus, to achieve a complete sterilization by disposing of microorganisms.

The medical waste autoclave devices which work through the very same logic kill microorganisms and viruses comprised in the medical waste and make them harmless. The pre-grinding systems available on the market first grind the intact medical waste within a closed system, then inactive the waste of which surface area has expanded, by exposing it to the pressurized steam at a high-degree temperature. The active duration for the pressurized steam to enable sterilization is 15 minutes in $121^{\circ} \mathrm{C}$, and 30 minutes in $115^{\circ} \mathrm{C}$. When it comes to the time-temperature parameters, the duration of sterilization decreases by the increase in temperature. However, for medical wastes, what is suggested is their nonstop subjection to a 1-4 hour-operation with a minimal temperature of $121^{\circ} \mathrm{C}$ and a pressure of $2-5$ bar (200$500 \mathrm{kPa})$. [29]

The autoclave sterilization clearly exceeds further the expectation that an adequate chemical treatment should be able to inactivate $99.99 \%$ of the microorganisms in the waste, that is a level of $4 \log 10$. On the other hand, the autoclave sterilization provides the killing of microorganisms in all their forms to a level of $6 \log 10$ or higher. This simply means that a least $99.9999 \%$ of the original spores of B. stearothermophilus have been destroyed in the waste, or that only one spore or less has survived the treatment from a population of one million spores. As it can be seen, there is an obvious difference between any chemical treatment and autoclave sterilization.[29]

\section{Advantages of the Autoclaves}

As already mentioned, the autoclaves are not a new system, it is a technology that have been already used in hospitals which has been widely accepted in many countries in terms of 
medical waste treatment. They present such facilities as large availability on the market by virtue of capacity, size and volume.

Although they are a type of hazardous medical waste treatment systems, their emission values are almost non-existing. If exhaust tars outlet pipes are used in the systems, any harm against environment is being prevented by supporting with heat filters. Capital costs are relatively low. This type of technologies that are available on the market is mostly computerized systems, therefore it is possible to see and record the amount of the medical wastes transformed into household wastes.

\section{Disadvantages of the Autoclaves}

- $\quad$ Large and sharp entities (shredder or grinder) might be harmful.

- Penetration of the pressurized steam may cause an effective smell in the waste.

The household waste which comes out of the systems without drier or vacuum facilities gains weight because of the pressurized steam to which it has been subjected. The medical waste dumped will be lighter than the household waste gained. The autoclave technologies are not exactly a disposal method but it is a pre-requisite implementation to be done before the medical waste collection and transmission. Any tiny faults which may be done by those who collect and transmit threaten firstly their own health and life, then those of others around them. The autoclave technology which is actively used in hospitals is a factor which helps patient recover after surgery operations by disposing the surgical sets used in those operations of microorganisms on the one hand, it constitutes another factor which might affect community health in a way that if medical wastes are pulled out from hospitals without passing through this system, this may lead any disease onset for some people.

\section{ii. Microwaves Technology}

Microwaves technology simply refers to the inactivation of any hazardous factors in the medical waste with the help of microwaves applied to the water droplets in the waste. Without any external supplementation of water, hot air or pressure, the system works only with the help of microwaves. The microwave frequency to be applied for medical wastes is $2459 \mathrm{MHz}$, and the wavelength is $12.24 \mathrm{~cm}$.

This system which is commonly preferred in European countries is thought expensive and barely accepted by the Middle East countries. Not as many as those which produce autoclave technologies, there is a number of firms which develop this technology. A certain range of wastes can be treated in a microwave except for volatile and semi-volatile organic compounds, chemotherapeutic wastes, mercury, other hazardous chemical wastes, and radiological wastes.

\section{Advantages of the microwave technology}

- Microwave technology has simply no difference with the household microwave ovens, and they are preferable.

- The emissions from microwave units are minimal.

- $\quad$ Even some models on the market do not give out any liquid effluents.

- $\quad$ By using grinders, a volumetric reduction of $80 \%$ in the waste can be observed. 
There is no difficulty with the use of the technology, and it can be used with one single operator.

\section{The disadvantages of the microwave technology}

- $\quad$ There may be some offensive odors around the device.

- The capital cost is relatively high.

- $\quad$ The large and sharp entities (shredder or grinder) may be harmful.

iii. Dry heat (hot air) Thermal Technologies

Dry heat (hot air) Thermal Technologies present an applicable technology which destroys microorganisms by hot air formed on the surface on which the medical waste is located, using only heat without any pressurized steam and water.

Some technologies are based on the hot wall application in which the waste is heated up by the hot walls of the chamber through conduction and natural convection whereas other technologies use radiant heating by means of infrared and quartz heaters. In comparison to steam-based processes, dry heat processes principally use higher temperatures and shooter exposure times. However, the properties and size of the wastes are determining factors on the time-temperature requisites.[28]

Both systems present similarities with autoclaves and microwaves in terms of the object of the treatment such ascultures and stocks, sharps, materials contaminated with blood and body fluids, isolation and surgery wastes, laboratory wastes (excluding chemical waste), and soft wastes (gauze, bandages, drapes, gowns, bedding, etc.) from patient care. Although the technology allows for human anatomical wastes to be treated, there are ethical, legal, cultural disagreements preventing the use of this technology on these subjects.

In certain systems with exhaust outlet pipes, it is possible to filter by using a combination of HEPA, carbon filters and venture scrubber which reduces offensive odors to a minimal level.

\section{Advantages of the dry heat thermal technology}

- Its structure is not too complicated in terms of design.

- It is a reliable system to inactivate wet and liquid wastes (body fluid, blood, etc.).

- $\quad$ There is no liquid effluents.

- There is a volumetric reduction of $80 \%$ in the models with internal shredders.

- It can be used by one single operator.

\section{Disadvantages of the dry heat thermal technology}

- $\quad$ Large and sharp entities (shredder or grinder) might be harmful.

- It may not be preferable for hospitals due to considerable power expenditure.

- There may be some offensive odors around the device.

In Table 7 some of non-incineration technologies listed. For further information, detail can see reference list. 


\begin{tabular}{|ll|}
\hline Non-incineration Technology & \multicolumn{1}{c|}{ Technology name, vendor } \\
\hline \multicolumn{2}{|c|}{ LOW-HEAT THERMAL PROCESSES } \\
\hline Autoclave or Retort & Tuttnauer \\
\hline Shredding-Steam-Mixing/Drying & Ecodas \\
\hline Steam-Mixing-Fragmenting/Drying & Hydroclave Systems Corp. \\
\hline Shredding-Steam-Mixing/Drying, Chemical & Steriflash, T.E.M. \\
\hline Vacuum-Steam/Drying/Shredding & Sterival, Starifant Vetriebs GmbH \\
\hline Shredding-Steam/Drying, Chemical & STI Chem-Clav, Waste Reduction Europe Ltd \\
\hline Shredding-Steam-Mixing/Compaction & STS, Erdwich Zerkleinerungssysteme GmbH \\
\hline
\end{tabular}

\begin{tabular}{|c|c|}
\hline Non-incineration technology & Technology name, vendor \\
\hline Vacuum-Steam/Drying/Shredding & System Drauschke, GÖK Consulting AG \\
\hline Steam-Fragmenting/Drying & ZDA-M3, Maschinenvertrieb für Umwelttechnik GmbH \\
\hline Microwave Treatment & Ecostéryl, AMB S.A. \\
\hline Microwave Treatment & Medister, Meteka \\
\hline Microwave Treatment & Sanitec \\
\hline Microwave Treatment & Sintion, CMB Maschinenbau und Handels $\mathrm{GmbH}$ \\
\hline $\begin{array}{l}\text { Vacuum-Steam/Microwave } \\
\text { Treatment/Drying/Shredding }\end{array}$ & Sterifant Vertriebs GmbH \\
\hline \multicolumn{2}{|c|}{ CHEMICAL PROCESSES } \\
\hline Fragmenting-Steam- $\mathrm{NaClO} / \mathrm{Cl}_{2} \mathrm{O}$ & Newster, Multiservice First s.r.l. \\
\hline Alkaline Hydrolysis & WR $^{2}$, Waste Reduction Europe Ltd \\
\hline \multicolumn{2}{|c|}{ IRRADIATION PROCESSES } \\
\hline Electron Beam-Shredding & U. Miami E-Beam \\
\hline \multicolumn{2}{|c|}{ BIOLOGICAL PROCESSES } \\
\hline- & Today not available in Europe \\
\hline
\end{tabular}

Table 7. Some of non-incineration technologies listed. For further information see Reference [28], [29]

\section{Conclusion}

When Medical Waste Treatment Technologies are presented as an example for Biomedical Instrument Application, it has been revealed that the technologies which can be used in different areas are also applicable for different purpose. Therefore they may have direct or indirect effects on human health. 
For example, while the autoclave technologies that have been used in hospitals for years are systems which help patients recover by disposing the surgical sets used in operations of microorganisms (if this system is used correctly, it efficiently reduces the risk of infection for the patient), they are necessary to be applied during the medical waste collection and transmission in order to eliminate all possible risks although they are not exactly disposal methods in low-heat thermal technologies. Any tiny faults which may be done by those who collect and transmit threaten firstly their own health and life, then those of others around them. While hospitals are certain places for some people to find their remedies, they should not become a kind of place which causes some people to get diseases.

As rules and laws vary depending on countries, this chapter is written in order to give a presentation of and raise an awareness on the operations in Asia, Europe and America. For example, while there is no permission for medical waste storage in European countries, hospitals in Asia and non-member of EU are storing their medical wastes in those hospitals for weeks and even months, or leave them on the streets without protection and lead to a danger against environment. Street animals become agents of an unhealthy cycle by carrying those microbes to humans. Unconscious Landfilling operated in some countries, as shown, has a negative effect on human life. The increase in the world population along with the carelessness in taking necessary precautions on time makes the subject more crucial, even it has been tried to attract attention to the awareness of the significance of the problem by some social organizations.

While the developed countries pride themselves on the medical waste statistics of their hospitals, a low level of medical waste extracted can be considered as a matter of success in some countries. The developing technologies and the investments of health care sector indicate that the care for human health is only possible to use different materials for each patient and prevent possible risks rather than using the same materials again and again. The infection and medical waste statistics among hospitals should be declared by the relevant authorities, a competence between hospitals should be raised.

The statistics to be published will show that people will prefer the hospitals with low infection and high medical waste statistics in the countries in which they live.

As an interdisciplinary area, biomedical has taught us the methods for considering different matters from different aspects. We should expose what we can do, both technologically and instrumentally, on the matters of which we have a certain level of true knowledge and thoughts. We should know how to sustain our lives without harming the world in which we live, without putting at risk others' lives. We should aim at leaving a living space for our future, for our children which will be better than what we have had.

For further information, primary references used in this chapter of the book are recommended: Safe Management Wastes from Health-care Activities co-edited by A. Prüss, E. Giroult, P. Rushbrook which was published by World Health Organization in GENEVA in 1999; and "Non--Incineration Medical Waste Treatment Technologies: A Resource for Hospital Administrators, Facility Managers, Health Care Professionals, Environmental Advocates, and Community Members" prepared by Dr. Jorge Emmanuel in 2004 which was issued by Health Care Without Harm. 


\section{References}

[1] The Ministry of Environment of Turkish Republic, (22 June 2005/25883). “The Regulation for Medical Waste Control" available at www.cygm.gov.tr/CYGM/Files/mevzuat/yonetmelik/tibbi.doc Accessed 01 January, 2012.

[2] World Health Organization (WHO), (November 2011) available at http://www.who.int/mediacentre/factsheets/fs253/en/ Accessed 12 January, 2012.

[3] Batterman S. (2004). Findings on an Assessment of Small-scale Incinerators for Healthcare Waste. WHO, Geneva, Switzerland.

[4] Directive 75/442/EC and transposed in order to obtain a cognitive national and European data on waste. (15.07.1975)

[5] Directive 2006/12/ECC Of The European Parliament And Of The Council of 5 April 2006 on waste (O.J. L 114, 27.04.2006)

[6] The Commission Resolution, Decision 2000/532/EC of 3 May 2000 replacing Decision 94/3/EC establishing a list of wastes pursuant to Article 1(a) of Council Directive 75/442/EEC on waste and Council Decision 94/904/EC establishing a list of hazardous waste pursuant to Article 1(4) of Council Directive 91/689/EEC on hazardous waste (O.J. L 226, 06.09.2000).

[7] Council Directive 91/689/EEC of 12 December 1991 on hazardous waste (O. J. L 377 , 31.12.1991).

[8] WHO Safe management of wastes from health-care activities co-edited by A. Prüss, E. Giroult, P. Rushbrook which was published by World Health Organization in GENEVA in 1999

[9] Baldwin, CL; Runkle, RS, (1967) Biohazards Symbol: Development of a Biological Hazards Warning Signal, volume 158 (issue 3798): page 264-265

[10] European Union Council Directive 67/548/EEC of 27 June 1967 on the approximation of laws, regulations and administrative provisions relating to the classification, packaging and labelling of dangerous substances

[11] The Ministry of Environment of Turkish Republic, (22 June 2005), “The Regulation for Medical Waste Control 25883" the Appendix 2

[12] Official Journal of the European Communities (16 January 2001), (2001/118/EC), available at http:/ / eur-lex.europa.eu/LexUriServ/LexUriServ.do?uri=OJ:L:2001:047:0001:0031 :EN:PDF Accessed 11 September, 2011.

[13] AODA, (America's Ocean Dumping Act) picture available at ; http:/ / www.greenwala.com/channels/nature/blog/5741-The-Ocean-s-Top-25Deadliest-Pollution-Predators Accessed 12 October, 2011.

[14] WHO | Waste from health-care activities, Chapter 3: "Safe management of wastes from health-care activities" Table 3.2 Viral hepatitis B infections caused by occupational injuries from sharps, Available at www.who.int/entity/water.../020to030.pdf

[15] Ozturk M. (2009) Medical Waste Management in the Hazardous Waste Group, the Report of the Deputy Chair of the Environment Commission of the Grand National Assembly of 
Turkey Medical Waste Management in the Hazardous Waste Group, the Report of the Deputy Chair of the Environment Commission of the Grand National Assembly of Turkey

[16] Princeton University (2008), "Laboratory Waste Streams", Picture. 5. available at; http://web.princeton.edu/sites/ehs/biosafety/livevirusworker/decontamination. htm Accessed 10 Jan, 2012.

[17] Hazardous Waste Management Plan (HWMP), (1990), California Country of El Dorado, available at;

http://www.co.eldorado.ca.us/Government/EMD/HazardousMaterials/Medical _Waste.aspx

[18] UNEP (United Nations Environment Programme environment for development), (22 Jun 2007), "Waste pickers at the main Khartoum landfill site; Waste management is problematic throughout Sudan", available at

http:// postconflict.unep.ch/sudanreport/sudan_website/index_photos_2.php?ke $\mathrm{y}=$ waste $\% 20$ management Accessed 1 Jan 2012.

[19] Council Directive 1999/31/EC of 26 April 1999 on the landfill of waste entered into force on 16.07.1999. The deadline for implementation of the legislation in the Member States was 16.07.2001.

[20] Oeltzschner H, Mutz D (1996). Guidelines for an appropriate management of domestic sanitary landfills. Eschborn, Gesellschaft für Technische Zusammenarbeit.

[21] Batterman S, (Website Updated April 9, 2008), Mozambique Program for Healthcare facility waste treatment, The Regents of the University of Michigan School of Public Health (MSPH), available at http:/ / research.sph.umich.edu/project.cfm?deptID=2\&groupID=1\&projectID=18 Accessed 12 September, 2011.

[22] U.S. Environmental Protection Agency, (1995) “Emission Factor Documentation for AP42 SECTION 2.6 MEDICAL WASTE INCINERATION" North Carolina, available at http://www.epa.gov/ttnchie1/ap42/ch02/bgdocs/b02s03.pdf Accessed 12 April, 2012.

[23] Picken D. J. (2007). De Montfort medical waste incinerators. Available at http://www.mwincinerator.info/en/101_welcome.html Accessed 8 November, 2011.

[24] Adama S. (2003). Results of Waste Management in Africa 2003. Presentation at the Safari Park Hotel, Nairobi, Kenya, 18-20 September 2003

[25] Taylor E. (2003). Rapid Assessment of Small-scale Incinerators: Kenya, Final Draft

[26] Veronica D. B.(2002), Practical Action Technology Challenging poverty,( "Health-Care Waste Management in Developing Countries" available at

http://practicalaction.org/low-cost-medical-waste-incinerator Accessed 12 December, 2011.

[27] Directive 2000/76/EC of the European Parliament and of the Council of 4 December 2000 on the incineration of waste. Available at

http://www.central2013.eu/fileadmin/user_upload/Downloads/Document_Cent re/OP_Resources/Incineration_Directive_2000_76.pdf

[28] Emmanuel J. (June 2004) Non-Incineration Medical Waste Treatment Technologies $\mathrm{HCWH}$ 
[29] Ontario, (2002) “Non-Incineration Technologies for Treatment of Biomedical Waste" (Procedures for Microbiological Testing), Sections 19 and 27; Part XVII, Section 197. GUIDELINE C-17 


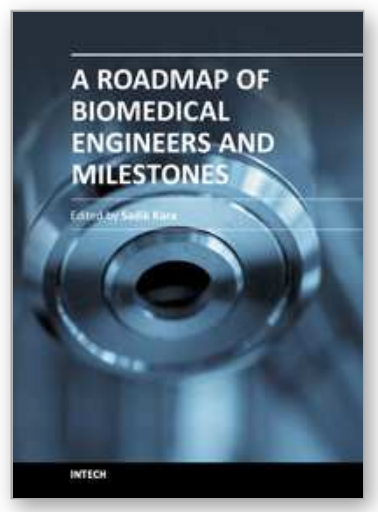

\author{
A Roadmap of Biomedical Engineers and Milestones \\ Edited by Prof. Sadik Kara
}

ISBN 978-953-51-0609-8

Hard cover, 230 pages

Publisher InTech

Published online 05, June, 2012

Published in print edition June, 2012

This book is devoted to different sides of Biomedical Engineering and its applications in science and Industry. The covered topics include the Patient safety in medical technology management, Biomedical Optics and Lasers, Biomaterials, Rehabilitat, Ion Technologies, Therapeutic Lasers \& Skin Welding Applications, Biomedical Instrument Aopplication and Biosensor and their principles.

\title{
How to reference
}

In order to correctly reference this scholarly work, feel free to copy and paste the following:

Muhammed Gulyurt (2012). Biomedical Instrument Application: Medical Waste Treatment Technologies, A Roadmap of Biomedical Engineers and Milestones, Prof. Sadik Kara (Ed.), ISBN: 978-953-51-0609-8, InTech, Available from: http://www.intechopen.com/books/a-roadmap-of-biomedical-engineers-andmilestones/biomedical-instrument-application-medical-waste-treatment-technolohgies

\section{INTECH}

open science | open minds

\author{
InTech Europe \\ University Campus STeP Ri \\ Slavka Krautzeka 83/A \\ 51000 Rijeka, Croatia \\ Phone: +385 (51) 770447 \\ Fax: +385 (51) 686166 \\ www.intechopen.com
}

\author{
InTech China \\ Unit 405, Office Block, Hotel Equatorial Shanghai \\ No.65, Yan An Road (West), Shanghai, 200040, China \\ 中国上海市延安西路65号上海国际贵都大饭店办公楼 405 单元 \\ Phone: +86-21-62489820 \\ Fax: +86-21-62489821
}


(C) 2012 The Author(s). Licensee IntechOpen. This is an open access article distributed under the terms of the Creative Commons Attribution 3.0 License, which permits unrestricted use, distribution, and reproduction in any medium, provided the original work is properly cited. 